\title{
AUTHORITARIANISM, ATTITUDES TOWARD HARM REDUCTION AND THE STIGMATISATION OF PEOPLE WHO USE DRUGS
}

\section{AUTORYTARYZM, POSTAWY WOBEC REDUKCJI SZKÓD I STYGMATYZACJA OSÓB UŻYWAJĄCYCH NARKOTYKÓW}

\author{
Geoff J. Bathje ${ }^{1}$ (ID), Daniel Pillersdorf ${ }^{2}$ (ID), Steve N. Du Bois ${ }^{3}$ \\ ${ }^{1}$ Adler University, Department of Counselor Education and Counseling, Chicago, USA \\ ${ }^{2}$ University of Windsor, Department of Psychology, Windsor, Canada \\ ${ }^{3}$ Illinois Institute of Technology, Department of Psychology, Chicago, USA
}

Alcohol Drug Addict 2019; 32 (2): 77-86 DOI: https://doi.org/10.5114/ain.2019.87624

\begin{abstract}
Introduction: While much research has been conducted in the past two decades on the stigma of mental health, relatively little has been published on the stigma of drug use and addiction, or attitudes toward harm reduction efforts. Although harm reduction is an approach particularly well suited for reducing the negative outcomes of drug use at a time when overdoses continue to escalate, negative opinions and anti-drug policies often interfere with the operation and funding of such programmes.

Material and methods: A diverse group of students in the United States $(N=193)$ completed an online assessment of authoritarian beliefs, fa-
\end{abstract}

Streszczenie

Correspondence to/Adres do korespondencji: Geoff J. Bathje, Adler University, Department of Counselor Education and Counseling, 17 N. Dearborn St., Chicago, IL, 60602, USA, phone: +1 312-662-4302, e-mail: gbathje@adler.edu

Authors' contribution/Wkład pracy autorów: Study design/Koncepcja badania: G.J. Bathje, D. Pillersdorf; Data collection/Zebranie danych: G.J. Bathje, D. Pillersdorf; Statistical analysis/Analiza statystyczna: G.J. Bathje, S.N. Du Bois; Data interpretation/Interpretacja danych: G.J. Bathje, D. Pillersdorf, S.N. Du Bois; Acceptance of final manuscript version/Akceptacja ostatecznej wersji pracy: G.J. Bathje, D. Pillersdorf, S.N. Du Bois; Literature Search/Przygotowanie literatury: G.J. Bathje, D. Pillersdorf.

No ghostwriting and guest authorship declared./Nie występują zjawiska ghostwriting i guest authorship.

Submitted/Otrzymano: 01.04.2019 • Accepted/Przyjęto do druku: 19.06.2019

(C) 2019 Institute of Psychiatry and Neurology. Production and hosting by Termedia sp. z o.o.

This is an open access article under the CC BY-NC-ND license (http://creativecommons.org/licenses/by-nc-nd/4.0/) 
miliarity with addictions, familiarity with intravenous drug use, stigmatisation of people who use drugs and attitudes toward harm reduction programming. We tested two mediation models to examine the relationship between authoritarianism, stigmatisation of people who use drugs and attitudes toward harm reduction, with familiarity to people experiencing addiction and injecting drugs as moderators.

Results: Authoritarianism was significantly associated with both attitudes toward harm reduction and stigmatisation of people who use drugs, with the relationship fully mediated by familiarity with people who inject drugs or who are experiencing addiction.

Discussion: The results of our study suggest that providing accurate and non-stigmatising information about drugs may reduce stigma and encourage openness to harm reduction programming.

Conclusions: As fatal drug overdoses and hepatitis $\mathrm{C}$ infections are continuing to rise, it is important to remove the barriers to both the creation and utilisation of harm reduction services.

Keywords: Harm reduction, Stigma, Drug use, Addiction, Authoritarianism
Materiał i metody: Zróżnicowana społeczno-demograficznie grupa amerykańskich studentów $(N=193)$ wypełniała online ankietę, na podstawie której oceniano: przekonania dotyczące autorytaryzmu, znajomość tematu uzależnień i iniekcyjnego przyjmowania narkotyków, stygmatyzację osób używających narkotyków oraz postawy wobec programów redukcji szkód. Aby zbadać związek między autorytaryzmem, stygmatyzacją osób używających narkotyków i postawami wobec programów redukcji szkód, przetestowano dwa modele z udziałem zmiennych pośredniczących: kontakt $\mathrm{z}$ osobami uzależnionymi i kontakt $\mathrm{z}$ osobami iniekcyjnie przyjmującymi narkotyki.

Wyniki: Stwierdzono, że autorytaryzm jest znacząco związany zarówno z postawami wobec programu redukcji szkód, jak i ze stygmatyzowaniem osób używających narkotyków, przy czym ta zależność była modyfikowana przez znajomość z osobami iniekcyjnie przyjmującymi narkotyki lub uzależnionymi.

Omówienie: Jak można sądzić na podstawie wyników badań, dostarczanie dokładnych i niepiętnujących informacji o narkotykach powinno zmniejszyć stygmatyzację i zachęcić do otwartego spojrzenia na program redukcji szkód.

Wnioski: Ze względu na zwiększającą się liczbę zgonów z powodu przedawkowania narkotyków i liczbę zakażeń wirusem zapalenia wątroby typu C należy rozważyć ograniczenie barier strukturalnych dla programów redukcji szkód.

Słowa kluczowe: redukcja szkód, stygmatyzacja, używanie narkotyków, uzależnienie, autorytaryzm

\section{- INTRODUCTION}

Harm reduction programming is as important as ever in light of the overdose epidemic and escalating rates of hepatitis C. Worldwide, about 275 million people used illicit drugs at least once in 2016, and about 450,000 people died from drug use in 2015 [1]. Of these deaths, approximately $1 / 3$ were a result of overdose and $2 / 3$ were a result of other drug related injury or infection, such as HIV and hepatitis C. In the United States, opioid overdose deaths almost tripled from 1999 to 2014 [2]. In 2017 the U.S. experienced 70,237 overdose deaths - around 192 each day - the most of any country [3].
Harm reduction is a philosophy and praxis that aims to reduce the adverse consequences of drug use, while respecting autonomy of the individual [4]. Certain harm reduction practices, such as needle exchange programmes (NEPs) have clear benefits, such as reducing HIV risk behaviour [5]. Despite the benefits of NEPs, these programmes are often met with public opposition. Some common misperceptions of NEPs include beliefs that crime will increase, that they enable or increase drug use, that they will attract more people who use drugs (PWUDs), or that individuals will be exposed to used syringes [6]. The degree of support for harm reduction programmes varies from nation to nation and regionally within countries. 
Arguably, negative sentiments regarding harm reduction programming stem largely from four international drug treaties that have shaped global drug policies and opinions. These include the 1931 Convention for Limiting the Manufacture and Regulating the Distribution of Narcotic Drugs, the 1961 Single Convention on Narcotic Drugs, the 1971 Convention on Psychotropic Substances and the 1988 Convention against Illicit Traffic in Narcotic Drugs and Psychotropic Substances.

Advocacy efforts such as drug laws aiming to reduce drug harms often focus on prevalence reduction, or the reduction of the total number of people using drugs [7]. This 'abstinence only' approach reflects an idealised belief that drug use can be eliminated. Conversely, harm reduction approaches are flexible to treatment plans that do not include elimination of drug use. A common argument against harm reduction is that this approach can be interpreted as communicating a measure of approval or encouragement for drug use. This contributes to stigmatised cultural beliefs about drug use while ignoring the effectiveness of harm reduction strategies [7]. In some incidents in the U.S., public opposition to harm reduction programmes has led to the termination of existing NEPs [8]. Given that attitudes toward harm reduction have been shown to influence public accessibility to harm reduction services, it would be valuable to better understand the factors that relate to supporting or opposing harm reduction efforts.

Four constructs that are empirically linked across various studies include authoritarianism, stigmatisation of people experiencing addiction, attitudes toward harm reduction, and familiarity with people who use drugs or who experience addiction. However, we are not able to identify any prior research that has examined all of these variables in one study. Each construct will be discussed in more detail below.

Right-wing authoritarianism is characterised by willingness to submit to authorities, valuing of uniformity, adherence to societal conventions and norms, and hostility or punitive attitudes to people who do not adhere to norms and conventions [9]. Those who espouse, follow, and attempt to impose such beliefs are often described as right-wing authoritarians [10]. As Altemeyer [11] notes, "right-wing" is used in a social psychological sense, as authorities perceived as established and legitimate receive public support more readily.
Authoritarian beliefs appear relevant to attitudes towards people who use drugs, and illegal drug use in particular. In a series of studies conducted by Peterson, Doty, and Winter [12], undergraduate students who scored higher on authoritarianism scales were more likely to have punitive sentiments and support stricter solutions for drug problems. In a study conducted in Norway, individuals scoring higher in authoritarian beliefs were found to make more judgments of personal responsibility, which negatively affected their willingness to support public funding to help people with addiction [13]. Corrigan, Schomerus, and Smelson [14] note that discrimination against PWUDs is accepted by society. Indeed, the use of many drugs, such as opioids, is illegal and treated criminally. Moreover, problems with drug use and addiction are not treated the same as physical disability or other mental health issues in many jurisdictions (e.g. Disabilities Rights Acts tend not to require accommodations in the workplace or comparable employment protections for individuals with addiction). Conceivably, those espousing authoritarian attitudes may contest the utility and even existence of harm reduction services, especially in contexts where these beliefs are reinforced by discriminatory societal norms against the use of drugs. Indeed, as discussed by Husak [15], many individuals believe the mere act of using drugs is immoral, that drug use may lead to other more wrongful acts, or that the use of drugs may prevent pro-social behaviour (e.g. productive workers; good parenting). Notwithstanding, other research has suggested that embracing a more liberal political stance is associated with higher support for NEPs [16].

Stigmatisation is another important concept in the approach to attitudes toward drug use and harm reduction programmes. Link and Phelan [17] define stigma as a co-occurrence of its components: labelling, stereotyping, separation, status loss and discrimination. For this reason, we choose to use the term "people who use drugs" rather than labels such as "addict" or "drug user". The authors also assert that stigmatisation requires the dominant group to possess power that allows them to discriminate against the non-dominant group. Because the majority of American citizens are not PWUDs or users of harm reduction programmes, the current beliefs of the majority group determine whether high levels of stigma surround drug use, addiction, addiction treatment and the use 
of harm reduction services. Goddard [18] found that attitudes toward harm reduction programmes become more positive after people learned about their benefits and reasons for their existence; i.e. they became more familiar with them. Relatedly, in both Australia [6] and Canada [19], where residents have gained exposure to comprehensive harm reduction programmes through living in neighbourhoods affected by injection drug use, steady increases in positive attitudes towards harm reduction have been observed. Such public support is crucial to promoting harm reduction policy. For example, positive public attitudes supported by scientific research were attributed to helping overturn a U.S. ban on federal funding for NEPs in 2009 [20]. Other research has confirmed the converse scenario, where low familiarity with harm reduction is associated with relatively negative attitudes toward such programmes [21].

The stigmatisation of PWUDs may also be impacted by familiarity, knowledge, and personal exposure to the people who use drugs. Research has shown that increased familiarity with people experiencing addiction decreases stigma towards them, particularly with regard to lower levels of perceived dangerousness, fear, and desired social distance [22]. McGinty, Goldman, Pescosolido, and Barry [23] found that when individuals are exposed to the idea that drug addiction can be treated successfully, there is a tendency to be less stigmatising and discriminatory toward PWUDs than if this concept is not conveyed. Given that intergroup contact is effective in decreasing anxiety and perceived threat among intolerant individuals toward out-group members [24], it follows logically that reducing stigmatising attitudes through increased positive contact, or exposure, may lead to greater willingness to support PWUDs, and correspondingly to more support for treatment programmes and harm reduction programmes. Several studies by Corrigan and colleagues suggest positive contact can be an effective strategy to decrease stigmatising attitudes toward addiction [25-27].

In the present study, we sought to better understand the relationships between authoritarian attitudes in general, stigma toward addiction and people who use drugs, attitudes toward harm reduction programmes, and familiarity with people experiencing addiction and familiarity with intravenous drug use. Our two hypotheses were that:
1) general authoritarian attitudes would positively predict stigmatising beliefs toward persons experiencing addiction, and the association would be mediated by familiarity with persons experiencing addiction and 2) general authoritarian attitudes would predict negative attitudes toward harm reduction programmes (most of which target intravenous drug use), and the association would be mediated by familiarity with intravenous (IV) drug use. We developed these two models, rather than a single path model, based on the level of specificity of our variables (i.e. the stigma and familiarity with addiction scales focused on addiction in general, while familiarity with IV drug use and attitudes toward harm reduction scales focused more on IV drug use).

\section{- Material ANd methods}

\section{Participants and procedures}

Psychology and sociology course instructors from community colleges and technical colleges in seven U.S. states (California, Illinois, Oklahoma, New York, Louisiana, Idaho, and Ohio) were sent an unsolicited email which provided an explanation of the study and gave the opportunity to invite their students to participate. All participating instructors were provided with the study's approved IRB protocol before distributing the survey to their students. Participants completed the online survey via Survey Monkey. Incentive to participate, such as extra credit, was left to the discretion of the individual course instructor. In the case where instructors offered extra credit incentive, students who did not wish to participate were offered a non-research alternative (writing a reflection paper). Instructors were provided with results of the study, in presentation format, for teaching purposes as an incentive to participate.

\section{Measures}

Harm Reduction Attitudes/Acceptability Scale (HRAS) [18]. A 25-item questionnaire assessing harm reduction acceptability. The scale measures personal attitudes towards harm reduction. Items are rated on a 5-point Likert scale ranging from 1 (strongly disagree) to 5 (strongly agree). The items primarily focus on support for 'abstinence only' versus non-abstinence drug policies, and attitudes toward specific harm reduction interventions primarily focused on injection drug use and opiate 
use (including methadone). The scale has high internal consistency, $\alpha=0.88$ to 0.93 , with $\alpha=0.77$ in the present study.

Familiarity with Addiction (FWA) and Familiarity with Intravenous Drug Use (FWIVDU). This scale was adapted for the current study from the Level of Contact Report by Holmes, Corrigan, Williams, Canar, and Kubiak [28]. The adapted FWA scale is an 11-item measure of familiarity with, and exposure to, people experiencing addiction. Each statement on the survey reflects a more intimate level of exposure to people with addiction, and the checked item with the highest rating is the measure of the participant's familiarity. We also created a version specific to IV drug use (FWIVDU) to examine familiarity with people who inject drugs apart from explicit mention of addiction. Holmes et al. [28] found the original survey to have good interrater reliability $(\kappa=0.83)$. In the present study, the internal consistency estimate was adequate for the FWA $(\alpha=0.69)$ and FWIVDU $(\alpha=0.82)$ subscales.

Right Wing Authoritarianism Scale-Revised (RWA-R) [29]. The RWA-R measures two dimensions of authoritarianism: conservatism (RWA-C), and authoritarian aggression and submission (RWA-AAS). The conservatism subscale includes items that are traditionally associated with, or in opposition to, conservative political ideology (e.g. "Homosexuals and feminists should be praised for being brave enough to defy traditional family values"), while the AAS subscale includes items related to deference to authority, enforcement of rules, and punishment ("What our country needs most is disciplined citizens, following national leaders in unity"). The scale has 15 , seven-point Likertstyle items. In the present study, the consistency was adequate for both Conservatism $(\alpha=0.75)$ and AAS $(\alpha=0.72)$ subscales.

Addiction Attribution Questionnaire (AAQ-S) [30]. This measure was adapted for the current study from the Attribution Questionnaire - Short Form, which was developed using the nine strongest loading items from the full 27 item version of the scale (AQ-9) [30]. The AAQ-S assesses public stigma towards individuals with addiction. The instrument contains nine items to assess emotional reaction and discriminatory responses to people with addictions in general, and is rated on a seven-point Likert-style scale. Internal consistency for the present study was $\alpha=0.73$.

\section{Data analytic strategy}

Analysis was completed using SPSS v24.0. For our primary analysis of mediation model testing, we used Hayes' [31] PROCESS macro to run multiple regression analyses. PROCESS was chosen for two reasons: First, PROCESS remains useful to test single mediator models like the ones proposed, and can uncover significant effects masked by more complex model testing [32]. Other analytic approaches like path analysis remain useful to test more complex models, e.g. those including moderated mediation [33]. Second, and as evidence of the first point, PROCESS has been used to test mediation models in comparable recent studies on stigma and health (e.g. [34]).

Statistical significance for mediation model testing was determined by inspecting the produced confidence intervals of the indirect (i.e. mediating) effect - yielded from 5,000 bootstrapped samples - at the 0.05 a level. Intervals excluding zero indicated a statistically significant indirect effect. In the case of significant mediation, we also calculated mediation effect sizes, which was the ratio of the indirect effect to the total effect [35]. For mediation analyses, demographic variables known to relate to model variables were entered as covariates, which included age, race/ethnicity, family income, gender and sexual orientation [36]. Exact $p$-values are provided except when $p<0.000$, as PROCESS does not provide specific $p$-values below this.

\section{- Results}

\section{Sample characteristics}

A diverse sample of 193 students was recruited. Participants described their communities as suburban (41.5\%), urban (37.8\%), rural (20.2\%) with $1.0 \%$ not responding. Participant age ranged from 18 to 57 years (mean $=25.2$ years). Demographic data was collected with regard to gender (74.6\% female, $24.4 \%$ male, $0.5 \%$ gender-fluid, with $0.5 \%$ not responding), sexual orientation $(86.0 \%$ heterosexual, $6.2 \%$ bisexual, $3.6 \%$ gay/lesbian, $0.5 \%$ gynesexual, with $4.1 \%$ not responding), race/ethnicity (46.1\% White/Caucasian, 19.7\% Hispanic/Latinx, 15.5\% Asian/Asian American, 14.0\% Black/African American, 3.6\% Biracial/Multiracial, with $1.0 \%$ not responding), and self-reported socioeconomic class $(13.0 \%$ lower, $34.2 \%$ lower middle, $40.0 \%$ middle, $12.4 \%$ upper middle, $0 \%$ upper with $1.0 \%$ not responding). 
$\underline{\text { Model } 1}$

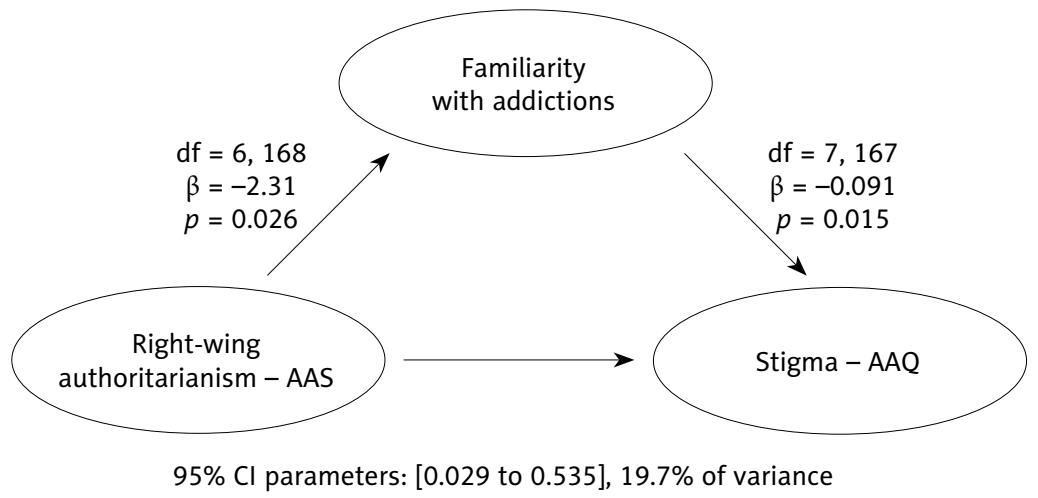

Model 2

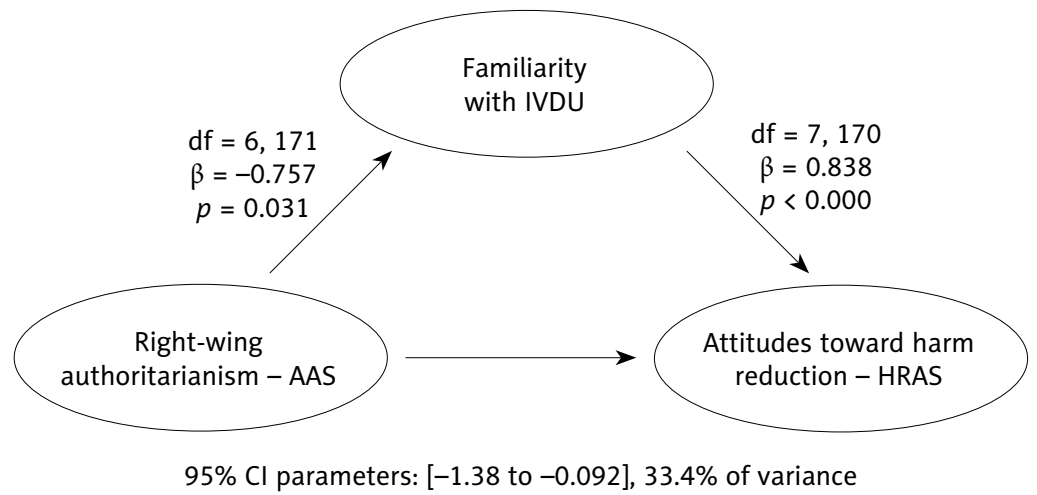

Figure 1. Significant mediation models, including model covariates

\section{Mediation model testing}

We aimed to test four original mediation models, to better understand the role of the RWA-R subscales on stigma and attitudes toward harm reduction. Because the RWA-R subscales correlated differently to the other variables in the study, we decided to examine them separately instead of combining them. Models 1 and 2 included the RWA-AAS (Authoritarian Aggression and Submission) subscale score as the independent variable. Model 1 tested FWA (Familiarity with Addictions) as the mediator and stigma as the dependent variable. Model 2 tested FWIVDU (Familiarity with Intravenous Drug Use) as the mediator and harm reduction programme attitudes as the dependent variable. Models 3 and 4 were identical, except they included RWA-C (Conservatism) subscale score as the independent variable.

Only the RWA-AAS subscale, and not the RWA-C subscale, was significantly associated with the proposed mediators. Mediation criteria were met for both models 1 and 2, including RWA-AAS as the independent variable when covariates were included (see Figure 1). In model 1, FWA explained $19.7 \%$ of the variance in stigmatisation of PWUD. Results for model 1 did not differ as a function of covariate inclusion. In model 2, FWIVDU explained $33.4 \%$ of the variance in attitudes toward harm reduction programmes. For model 2, when including covariates, the model became insignificant and associations between both RWA-AAS and the mediator (FWIVDU) and the mediator with the dependent variable (attitudes toward harm reduction) also became insignificant (see Figure 1). No covariates were associated significantly with the mediator, while gender and sexual orientation both related to attitudes toward harm reduction. Specifically, female gender and LGBQ sexual orientation related to more positive attitudes toward harm reduction (HRAS; $\beta=1.55, p=0.007$; $\beta=2.04, p=0.019$ respectively). When the RWA-C score was entered as the independent variable in models 3 and 4 , it did not predict the proposed mediator $(p>0.05)$; therefore, mediation criteria were not met, and subsequent mediation analyses were not performed. 


\section{- Discussion}

The present study points to some key factors that may influence a person's attitudes toward harm reduction and their stigmatising beliefs about addiction. Our findings may be of particular interest to proponents of harm reduction, who may find themselves having to convince others of the efficacy and appropriateness of their programming.

We explored one variable that is relatively traitlike - authoritarian beliefs - and three variables that have been found to be relatively malleable in prior research - familiarity, as the proposed mediator, and stigma and harm reduction attitudes as the proposed outcomes. While it may initially appear that authoritarian beliefs relate directly to stigmatising attitudes toward PWUDs and disapproval of harm reduction efforts, our mediation model suggests that is not the full picture. Interestingly, the Conservatism subscale of the RWAS was not strongly associated with stigma or attitudes toward harm reduction programming, suggesting that political ideology may not be the most relevant variable in advocating for the wellness of PWUDs. On the other hand, right wing authoritarian submission and aggression was associated with increased stigma and negative attitudes toward harm reduction, though this relationship was mediated by familiarity. Importantly, we measured both general familiarity with persons experiencing addiction and the more specific familiarity with people who use drugs intravenously. Both levels of familiarity acted as effective mediators, suggesting stigma might be reduced and harm reduction attitudes improved by working to raise awareness of accurate and non-stigmatising information about drugs and addiction, while creating opportunities for positive contact or humanising portrayals of people who use drugs or who become addicted.

The provision of accurate information about drugs and drug use has been long supported by harm reduction advocates [37]. Mental illness focused anti-stigma research provides additional avenues for reducing stigma, namely providing positive contact with persons with mental illness, emphasising our common humanity, and viewing their experiences on a continuum of human experience rather than through rigid diagnostic categories [28]. Additional research suggests that empathy in particular is associated with lower endorsement of stigmatising beliefs [38] and is essential in reducing prejudice in general [39]. Based on our findings, similar research appears warranted in the area of drug-related stigma.

The strong diversity of our sample enhances the generalisability of our findings. Our participants were racially/ethnically and economically diverse, lived in different regions of the U.S. and lived in different types of communities (rural, urban, and suburban). One study limitation was its cross sectional rather than longitudinal or experimental character, thus prohibiting causal conclusions. Additionally, our study was conducted within the United States, where cultural attitudes about drug use and drug policy may differ from other countries. However, international drug treaties create some similarities in drug policy around the world, particularly with regard to the focus on prohibition of non-medical use of many classes of drugs [40]. Our study may also be influenced by the lack of measures of stigma and attitudes specific to drug use and harm reduction, which required us to adapt existing measures. We hope that future studies will provide further measurement development and testing of our adapted measures.

Despite these limitations, based on our findings, experimental studies or interventions that increase familiarity with addiction and drug use through accurate information and positive contact seem warranted. It is our hope that such future work can yield approaches to reduce the stigma of addiction and improve attitudes toward harm reduction programming. As the number of fatal overdoses and hepatitis $\mathrm{C}$ infections continue to rise each year, it has become increasingly important to remove the barriers to both the creation and utilisation of harm reduction services.

\section{Acknowledgement/Podziękowania}

We would like to acknowledge the late Dan Bigg, director of Chicago Recovery Alliance and pioneer of peer use of naloxone for overdose prevention for inspiring our research on harm reduction and stigma as he has inspired countless others. 


\section{Conflict of interest/Konflikt interesów}

None declared./Nie występuje.

Financial support/Finansowanie

None declared./Nie zadeklarowano.

\section{Ethics/Etyka}

The work described in this article has been carried out in accordance with the Code of Ethics of the World Medical Association (Declaration of Helsinki) on medical research involving human subjects, EU Directive (210/63/EU) on protection of animals used for scientific purposes, Uniform Requirements for manuscripts submitted to biomedical journals and the ethical principles defined in the Farmington Consensus of 1997.

Treści przedstawione w pracy są zgodne z zasadami Deklaracji Helsińskiej odnoszącymi się do badań z udziałem ludzi, dyrektywami UE dotyczącymi ochrony zwierząt używanych do celów naukowych, ujednoliconymi wymaganiami dla czasopism biomedycznych oraz z zasadami etycznymi określonymi w Porozumieniu z Farmington w 1997 roku.

\section{References/Piśmiennictwo}

1. United Nations Office on Drugs and Crime (UNODC). World drug report 2018: Global overview of drug demand and supply. Vienna: United Nations Publication; 2018. http://www. unodc.org/wdr2018/prelaunch/WDR18_Booklet_2_GLOBAL.pdf [Access: 18.06.2019].

2. Rudd RA, Seth P, David F, Scholl L. Increases in Drug and Opioid-Involved Overdose Deaths - United States, 2010-2015. MMWR Morb Mortal Wkly Rep 2016; 65: 1445-52. doi: 10.15585/mmwr.mm655051e1

3. Hedegaard H, Miniño AM, Warner M. Drug overdose deaths in the United States, 1999-2017. NCHS Data Brief 2018; 329. https://www.cdc.gov/nchs/products/databriefs/db329.htm [Access: 18.06.2019].

4. Single E. Defining harm reduction. Drug Alcohol Rev 1995; 14(3): 287-90. doi: 10.1080/ 09595239500185371

5. Gibson DR, Flynn NM, Perales D. Effectiveness of syringe exchange programs in reducing HIV risk behavior and HIV seroconversion among injecting drug users. AIDS 2001; 15(11): 1329-41. doi: 10.1097/00002030-200107270-00002

6. White B, Haber PS, Day CA. Community attitudes towards harm reduction services and a newly established needle and syringe automatic dispensing machine in an inner-city area of Sydney, Australia. Int J Drug Policy 2016; 27: 121-6. doi: 10.1016/j.drugpo.2015.05.010

7. MacCoun RJ. Toward a psychology of harm reduction. Am Psychol 1998; 53(11): 1199208. doi: 10.1037//0003-066x.53.11.1199

8. Tempalski B, Flom PL, Friedman SR, Jarlais DC, Friedman JJ, Mcknight C, et al. Social and political factors predicting the presence of syringe exchange programs in 96 US metropolitan areas. Am J Public Health 2007; 97(3): 437-47. doi: 10.2105/ajph.2005.065961

9. Stenner K. Three kinds of "conservatism". Psychol Inq 2009; 20(2-3): 142-59. doi: $10.1080 / 10478400903028615$

10. Altemeyer B. The authoritarian specter. Cambridge, MA: Harvard University Press; 1996.

11. Altemeyer B. Right-wing authoritarianism. Winnipeg: University of Manitoba Press; 1981.

12. Peterson BE, Doty RM, Winter DG. Authoritarianism and attitudes toward contemporary social issues. Pers Soc Psychol Bull 1993; 19(2): 174-84. doi: 10.1177/0146167293192006

13. Halkjelsvik T, Rise J. Social dominance orientation, right-wing authoritarianism, and willingness to help addicted individuals: The role of responsibility judgments. Eur J Psychol 2014; 10(1): 27-40. doi: 10.5964/ejop.v10i1.669

14. Corrigan P, Schomerus G, Smelson D. Are some of the stigmas of addictions culturally sanctioned? Br J Psychiatry 2017; 210(3): 180-1. doi: 10.1192/bjp.bp.116.185421

15. Husak DN. The Moral Relevance of Addiction. Subst Use Misuse 2004; 39(3): 399-436. doi: 10.1081/ja-120029984 
16. Kulesza M, Teachman BA, Werntz AJ, Gasser ML, Lindgren KP. Correlates of public support toward federal funding for harm reduction strategies. Subst Abuse Treat Prev Policy 2015; 10(1). doi: 10.1186/s13011-015-0022-5

17. Link BG, Phelan JC. Conceptualizing Stigma. Annu Rev Sociol 2001; 27(1): 363-85. doi: 10.1146/annurev.soc.27.1.363

18. Goddard P. Changing attitudes towards harm reduction among treatment professionals: a report from the American Midwest. Int J Drug Policy 2003; 14(3): 257-60. doi: 10.1016/s0955-3959(03)00075-6

19. Rapid Response Service. Rapid response: Public perception of harm reduction interventions. Toronto: Ontario HIV Treatment Network; 2012.

20. Sharon S. Ban Lifted on Federal Funding for Needle Exchange. National Public Radio, 18 December 2009. https://www.npr.org/templates/story/story.php?storyId=121511681 [Access: 18.06.2019].

21. Beletsky L, Macalino GE, Burris S. Attitudes of police officers towards syringe access, occupational needle-sticks, and drug use: A qualitative study of one city police department in the United States. Int J Drug Policy 2005; 16(4): 267-74. doi: 10.1016/j.drugpo.2005.01.009

22. Janulis PF. Understanding addiction stigma: Examining desired social distance toward addicted individuals. College of Liberal Arts \& Social Sciences. Theses and Dissertations. Paper 16. Chicago: DePaul University; 2010. http://via.library.depaul.edu/etd/16 [Access: 18.06.2019].

23. McGinty EE, Goldman HH, Pescosolido B, Barry CL. Portraying mental illness and drug addiction as treatable health conditions: Effects of a randomized experiment on stigma and discrimination. Soc Sci Med 2015; 126: 73-85. doi: 10.1016/j.socscimed.2014.12.010

24. Hodson G. Do ideologically intolerant people benefit from intergroup contact? Curr Dir Psychol Sci 2011; 20(3): 154-9. doi: 10.1177/0963721411409025

25. Corrigan PW, Schomerus G, Shuman V, Kraus D, Perlick D, Harnish A, et al. Developing a research agenda for reducing the stigma of addictions, part II: Lessons from the mental health stigma literature. Am J Addictions 2017; 26(1): 67-74. doi: 10.1111/ajad.12436

26. Corrigan P, Michaels PJ, Morris S. Do the effects of antistigma programs persist over time? Findings from a meta-analysis. Psychiatr Serv 2015; 66(5): 543-46. doi: 10.1176/ appi.ps.201400291

27. Corrigan PW, Morris SB, Michaels PJ, Rafacz JD, Rüsch N. Challenging the public stigma of mental illness: a meta-analysis of outcome studies. Psychiatr Serv 2012; 63(10): 963-73. doi: 10.1176/appi.ps.005292011

28. Holmes EP, Corrigan PW, Williams P, Canar J, Kubiak MA. Changing attitudes about schizophrenia. Schizophr Bull 1999; 25(3): 447-56. doi: 10.1093/oxfordjournals.schbul.a033392

29. Rattazzi AM, Bobbio A, Canova L. A short version of the Right-Wing Authoritarianism (RWA) scale. Pers Individ Dif 2007; 43(5): 1223-34. doi: 10.1016/j.paid.2007.03.013

30. Corrigan PW, Powell KJ, Michaels PJ. Brief battery for measurement of stigmatizing versus affirming attitudes about mental illness. Psychiatry Res 2014; 215(2): 466-70. doi: 10.1016/j.psychres.2013.12.006

31. Hayes AF. Introduction to mediation, moderation, and conditional process analysis: A regression-based approach, $2^{\text {nd }}$ ed. New York: Guilford Press; 2018.

32. Starr LR, Hammen C, Connolly NP, Brennan PA. Does relational dysfunction mediate the association between anxiety disorders and later depression? Testing an interpersonal model of comorbidity. Depress Anxiety 2014; 31(1): 77-86. doi: 10.1002/da.22172

33. Edwards JR, Lambert LS. Methods for integrating moderation and mediation: a general analytical framework using moderated path analysis. Psychol Methods 2007; 12(1): 1-22. doi: 10.1037/1082-989X.12.1.1

34. Hunger JM, Major B. Weight stigma mediates the association between BMI and self-reported health. Health Psychol 2015; 34(2): 172-5. doi: 10.1037/hea0000106

35. Preacher KJ, Kelley K. Effect size measures for mediation models: quantitative strategies for communicating indirect effects. Psychol Methods 2011; 16(2): 93-115. doi: 10.1037/ a0022658 
36. Feldman S, Johnston C. Understanding the determinants of political ideology: Implications of structural complexity. Political Psychol 2014; 35(3): 337-58. doi: 10.1111/pops. 12055

37. Denning P, Little J. Practicing harm reduction psychotherapy: An alternative approach to addictions, $2^{\text {nd }}$ ed. New York: Guilford Press; 2011.

38. Bathje GJ, Pryor JB. The relationships of public and self-stigma to seeking mental health services. JMHC 2011; 33: 161-76. doi: 10.17744/mehc.33.2.g632039274160411

39. Bäckström M, Björklund F. Structural modeling of generalized prejudice: The role of social dominance, authoritarianism, and empathy. J Individ Differ 2007; 28(1): 10-7. doi: 10.1027/1614-0001.28.1.10

40. Room R. Reform by subtraction: The path of denunciation of international drug treaties and reaccession with reservations. Int J Drug Policy 2012; 23(5): 401-6. doi: 10.1016/j. drugpo.2012.04.001 